\title{
SURFACE MODIFIED AND BISMUTH LOADED GRAPHITE FELTS FOR IMPROVEMENT OF ANODE ELECTRODE KINETICS IN IRON CHROMIUM REDOX FLOW BATTERY
}

\author{
Mukaddes Candan KARAEYVAZ, Department of Chemical Engineering, Middle East Technical University, Turkey, \\ candankaraeyvaz@gmail.com \\ (iD) https://orcid.org/0000-0002-8130-2216) \\ *Berker FIÇICILAR, Department of Chemical Engineering, Ondokuz Mayıs University, Turkey, berker.ficicilar@omu.edu.tr \\ (iD https://orcid.org/0000-0003-3882-1691)
}

Received: 11.03.2020, Accepted: 03.06.2020

Research Article

*Corresponding author

DOI: $10.22531 /$ muglajsci.702286

\begin{abstract}
In this study, anode electrodes were modified and bismuth loaded to enhance chromium redox reaction for iron chromium redox flow batteries. Graphite felt anode electrode surface was modified by two step chemical treatment. Corrosive HF was used as an etchant to increase porosity at the first step and oxidizing $\mathrm{H}_{2} \mathrm{O}_{2}$ was used to increase wettability of electrode at the second step. Scanning electron microscopy (SEM) and X-ray photoelectron spectroscopy (XPS) analyses were used for the physical and chemical characterization of electrode materials. Cyclic voltammetry (CV) and linear sweeping voltammetry (LSV) techniques were conducted to investigate $\mathrm{Cr}^{2+} / \mathrm{Cr}^{3+}$ redox reaction kinetics for the modified electrodes with or without bismuth loading. Carbon nanoparticles formed on the surface and oxygen content increased. Contact angle for pristine graphite felt decreased from $132.6^{\circ}$ to $128.5^{\circ}$, electrode wettability increased after treatment with $\mathrm{HF}$ and $\mathrm{H}_{2} \mathrm{O}_{2}$. Dispersion of bismuth particles became more uniform on modified electrode. Compared to untreated felt, the diffusion coefficient for $\mathrm{Cr}^{2+}$ has been almost doubled on modified graphite felt and $\mathrm{Cr}^{2+}$ concentration on the surface increased. When bismuth was in solution, reaction was controlled by charge transfer for modified electrode. In contrast, when bismuth was loaded onto the felt electrodes, reaction became diffusion controlled.

Keywords: Graphite Felt, Acidic Modification, $\mathrm{Cr}^{3+} / \mathrm{Cr}^{2+}$ Electrode Kinetics, Fe/Cr Redox Flow Battery

\section{DEMIR KROM REDOKS AKIŞ PİLLERINNDE ANOT ELEKTROT KINNETİĞİNIN İYILEŞTİRILMESİ İÇIN YÜZEY MODİFİKASYONU YAPILMIŞ VE BİZMUT YÜKLENMİ̧ GRAFITT KEÇELER}

\section{Özet}

Bu çalışmada, demir krom redoks akış pillleri için krom redoks reaksiyonunu iyileştirmek amacıyla anot elektrotuna modifikasyon yapılmış ve bizmut yüklenmiştir. Grafit keçe anot elektrot yüzeyi iki aşamalı kimyasal işlem ile modifiye edilmiştir. İlk basamakta korozif $\mathrm{HF}$ aşındırıcı ajan olarak kullanılmışs, ikinci basamakta ise oksitleyici $\mathrm{H}_{2} \mathrm{O}_{2}$ ıslanabilirliğin artırılması için kullanılmıştır. Taramalı elektron mikroskopu (SEM) ve X-ışını fotoelektron spektroskopisi (XPS) analizleri elektrot malzemelerinin fiziksel ve kimyasal karakterizasyonunda kullanılmıştır. Bizmut yüklemesinin olduğu ve olmadığı durumda $\mathrm{Cr}^{2+} / \mathrm{Cr}^{3+}$ redoks reaksiyonu kinetiğinin anlaşılmasında çevrimsel voltametri (CV) ve doğrusal süpürmeli voltametri teknikleri kullanılmıştır. Yüzeyde karbon nanoparçacıkları oluşmuş, oksijen içeriği artmıştır. İşlem görmemiş grafit keçe için temas açısı $132.6^{\circ}$ den $128.5^{\circ}$ ye düşmüş, $\mathrm{HF}$ ve $\mathrm{H}_{2} \mathrm{O}_{2}$ ile işlem sonucunda elektrot ıslanabilirliği artmıştır. Bizmut nanoparçacıklarının dağılımı modifiye edilmiş elektrot üzerinde daha homojen hale gelmiştir. İşlem görmemiş elektrota klyasla, $\mathrm{Cr}^{2+}$ için difüzyon katsayısı modifiye edilmiş elektrot üzerinde neredeyse iki katına çıkmış, yüzeydeki $\mathrm{Cr}^{2+}$ konsantrasyonu artmıştır. Modifiye edilmiş elektrot için bizmut çözeltide olduğunda, reaksiyon yük transferi ile kontrol edilmektedir. Aksine, bizmut keçe elektotlara yüklendiğinde reaksiyon difüzyon kontrollü olmaktadır.

AnahtarKelimeler: Grafit Keçe, Asidik Modifikasyon, $\mathrm{Cr}^{3+} / \mathrm{Cr}^{2+}$ Elektrot Kinetiği, $\mathrm{Fe} / \mathrm{Cr}$ Redoks Akış Pili

Cite

Karaeyvaz, M. C., Fiçıcılar B., (2020). "Surface modified and bismuth loaded graphite felts for improvement of anode electrode kinetics in iron chromium redox flow battery", Mugla Journal of Science and Technology, 6(1), 95-104. 


\section{Introduction}

Due to industrial and technological developments, the world's electrical energy demand is accelerating and usable fossil fuel reserves are decreasing considerably. Intermittent renewable energy sources such as wind and solar power cause fluctuations problem during the day depending on the weather conditions. Electrical energy storage (EES) can be considered as a satisfactory solution to compensate the energy imbalance and consequently electrical energy can be supplied when needed. It is possible to store electrical energy in different forms in different systems. Electrical energy can be stored mechanically in the form of kinetic energy, mechanically in the form of potential energy, chemically (fuel cells, flow batteries and secondary batteries) and thermally by low and high temperature processes. Among these systems, redox flow batteries are an alternative promising and developing electrical energy storage technology. In redox flow batteries, the energy density and the power density can be independently scaled. Energy capacity is related to the tank size and concentration of the electroactive species, while power capacity is related to active cell area and the number of cells $[1,2]$. One way to decrease cell size and cost of the flow battery is to develop high performance anode and cathode electrodes. Redox flow battery systems such as polysulfide bromide, Iron-Chromium, Vanadium Redox, and Hydrogen-Bromine are promising electrochemical energy storage technologies. Considering iron/ chromium redox flow battery (ICRFB), iron and chromium based anolyte and catholyte solutions are used at the anode and cathode. These reactants are abundant and cheap materials, as well as ICRFBs have benefit according to economic considerations compared to vanadium redox flow batteries (VRFBs) when operated at the large scale as in smart grid applications [3].

$$
\begin{array}{ll}
\mathrm{Cr}^{2+}-\mathrm{e} \rightarrow \mathrm{Cr}^{3+} & 0.41 \mathrm{~V} \text { vs SHE } \\
\mathrm{Fe}^{3+}+\mathrm{e}^{-} \rightarrow \mathrm{Fe}^{2+} & 0.77 \mathrm{~V} \text { vs SHE } \\
\mathrm{Cr}^{2+}+\mathrm{Fe}^{3+} \rightarrow \mathrm{Cr}^{3+}+\mathrm{Fe}^{2+} & 1.18 \mathrm{~V} \text { vs SHE }
\end{array}
$$

Kinetics of the $\mathrm{Cr}$ side redox reaction is slow and $\mathrm{H}_{2}$ evolution reaction occurs during the charging process which competes with the $\mathrm{Cr}^{3+} / \mathrm{Cr}^{2+}$ reduction reaction For the $\mathrm{Fe} / \mathrm{Cr}$ flow batteries [4]. Electroactive welldesigned electrodes can improve the anode reaction kinetics while reducing hydrogen gas output. Among the carbon based electrodes, usage of graphite felt (GF) is more common owing to 3D structure, good electrochemical activity, chemical stability, and low cost [5], [6]. Various electrode modifications such as thermal treatment [7], [8], acidic treatment [9], [10], acidic and thermal treatment [11], electrochemical oxidation of GFs in acid solution [12], and $\mathrm{O}_{2}$ plasma treatment [13] are considered to enhance the surface properties of the electrode. Amount of surface functional groups, wettability of the electrode and consequently catalytic activity for redox reactions can be increased with the help of these treatments. These functional groups also facilitate the $\mathrm{Cr}^{3+} / \mathrm{Cr}^{2+}$ redox reaction specifically [14][16]. One of the other methods to increase catalytic activity is the usage of certain metal catalysts by internal [17] or external loading [18]-[20] over the porous transport layer (e.g. graphite felt). Especially, bismuth shows catalytic activity for both VRFBs [17][20] and $\mathrm{Cr}^{3+} / \mathrm{Cr}^{2+}$ redox reaction [15], [16], [21]. Increasing the surface roughness and area are not a satisfactory solution, modification method which has a favorable effect on both surface area and catalytic activity is seen as more beneficial [22]. In other words, usage of metal catalyst with a rough or porous electrode material can be more favorable. Porosity of carbon fiber-based electrodes mainly comprises voids between fibers and their surface area is quite low. Increase in surface area and porosity is not sufficient after treatments stated above. He et al. [23] used $\mathrm{HF} / \mathrm{H}_{2} \mathrm{O}_{2}$ treatment for GFs in VRFB. In their study, HF served as an etchant to increase available sites for redox reactions and $\mathrm{H}_{2} \mathrm{O}_{2}$ served as an oxidant. As a result, oxygencontaining functional groups and electrochemical activity of the electrode increased. Zhou et al. [24] used $\mathrm{KOH}$ activation for carbon paper electrode and obtained bimodal porosity. They increased the surface area of the electrode one order of magnitude compared to bare carbon paper. Zhou et al. also reported that bigger pores form pathways for electrolyte flow and smaller pores which connected to bigger ones contains active sites. In another study using $\mathrm{KOH}$ as the activating agent for GF, it was reported that edge carbon sites and functional groups were formed on the electrode surface, surface area was increased, and enhanced flow battery performance was achieved with the modified electrode for VRFBs [25]. Among these summarized studies $\mathrm{HF} / \mathrm{H}_{2} \mathrm{O}_{2}$ treatment is the promising one since porosity, surface area, wettability and as a result activity increase to a sufficient level. In the present study, two step $\mathrm{HF} / \mathrm{H}_{2} \mathrm{O}_{2}$ modification was used in order to investigate effect of $\mathrm{HF} / \mathrm{H}_{2} \mathrm{O}_{2}$ modified $\mathrm{GF}$ on the performance of $\mathrm{Cr}^{3+} / \mathrm{Cr}^{2+}$ redox reaction for the first time. Bismuth was loaded onto the GF electrodes by electrochemical deposition method. Electrocatalytic activity of the GF was tested with cyclic voltammetry and linear sweep voltammetry for electrolyte solutions with or without bismuth addition.

\section{Experimental}

PAN based GFD 2.5 EA graphite felt was supplied from $\mathrm{SGL}^{\circledR}$ group. $\mathrm{CrCl}_{3} \cdot 6 \mathrm{H}_{2} \mathrm{O}, \mathrm{HF}, \mathrm{H}_{2} \mathrm{O}_{2}$ and $\mathrm{Bi}_{2} \mathrm{O}_{3}$ were purchased from Sigma Aldrich, Merck, Tekkim and Alfa Aesar respectively. Graphite felts were pretreated prior to $\mathrm{HF} / \mathrm{H}_{2} \mathrm{O}_{2}$ treatment. Firstly, felts were immersed in acetone and kept in ultrasonic bath for $1 \mathrm{~h}$ and then immersed in deionized water and kept in ultrasonic 
bath for $1 \mathrm{~h}$. Afterwards, graphite felts were dried at $80^{\circ} \mathrm{C}$ followed by $2 \mathrm{~h}$ heat treatment at $150{ }^{\circ} \mathrm{C}$ in an oven [26], [27]. Pretreated GFs were immersed in $12 \mathrm{wt} \% \mathrm{HF}$ for $36 \mathrm{~h}$, washed with deionized water until neutral $\mathrm{pH}$ and dried at $80^{\circ} \mathrm{C}$. Oxidation of the $\mathrm{GF}$ was performed with 5 wt. $\% \mathrm{H}_{2} \mathrm{O}_{2}$ at $180^{\circ} \mathrm{C}$ for $10 \mathrm{~h}$ in a Teflon lined stainless steel autoclave. After $\mathrm{H}_{2} \mathrm{O}_{2}$ treatment GFs were washed with deionized water and dried at room temperature. Bismuth loading of $0.005 \mathrm{~g} / \mathrm{cm}^{2}$ on graphite felt was performed by electrochemical deposition method. Pt wire, $\mathrm{Ag} / \mathrm{AgCl}(3 \mathrm{M} \mathrm{NaCl}$ ) and $\mathrm{GF}$ were used as counter electrode, reference electrode, and working electrode respectively. $-0.5 \mathrm{~V}$ voltage was applied for the electrochemical deposition of bismuth. After deposition, graphite felts were thermally treated at $450^{\circ} \mathrm{C}$ for $0.5 \mathrm{~h}$. Pristine and modified graphite felt based electrodes prepared for voltammetry tests were named as $\mathrm{Bi} / \mathrm{GF}$ and $\mathrm{Bi} / \mathrm{HF}-\mathrm{GF}$.

Scanning electron microscopy (SEM, JEOL JSM-7001F) and X-ray photoelectron spectroscopy (XPS, PHI Versaprobe 5000, reference: $284.5 \mathrm{eV}$ binding energy) analysis were carried out to analyze textural and chemical properties of the prepared pristine GF, HF/GF, and $\mathrm{Bi}$ loaded graphite felts (Bi/GF and $\mathrm{Bi} / \mathrm{HF}-\mathrm{GF}$ ). Contact angle measurement was achieved by dynamic method for ten minutes, $5 \mu$ l water droplet was used on test. Electrochemical performance of felts on $\mathrm{Cr}^{3+} / \mathrm{Cr}^{2+}$ redox reaction was tested by cyclic voltammetry (CV) (Basi RDE-2 stand and Ivium potentiostat). Felt, platinum wire and $\mathrm{Ag} / \mathrm{AgCl}(3 \mathrm{M} \mathrm{NaCl})$ were used as working, counter and reference electrode respectively. Felts were immersed in ethanol for $1 \mathrm{~h}$, later in deionized water for $1 \mathrm{~h}$ and finally in electrolyte solution before CV tests as suggested by Smith et al. [28]. GF electrodes were hanged with Pt wire like fish hook (Fig. 1). Electrolyte solutions were $1 \mathrm{M} \mathrm{HCl}, 1 \mathrm{M} \mathrm{HCl}$ $+1 \mathrm{M} \mathrm{CrCl}_{3}$ and $1 \mathrm{M} \mathrm{HCl}+1 \mathrm{M} \mathrm{CrCl}_{3}+\mathrm{Bi}_{2} \mathrm{O}_{3}$. Scanned potential range was 1 to $-1.2 \mathrm{~V}$ except voltammograms of bismuth free electrodes, for these electrodes scanning was conducted between 1 to $-0.2 \mathrm{~V} . \mathrm{H}_{2}$ evolution on felts was monitored by linear sweeping voltammetry by using only acidic media $(1 \mathrm{M} \mathrm{HCl})$ in the potential range of 0 to $-1.2 \mathrm{~V}$. Scanning rate was kept at $100 \mathrm{mV} / \mathrm{s}$ in general and in some experiments altered to analyze electrochemical effects resulting from scan rate.

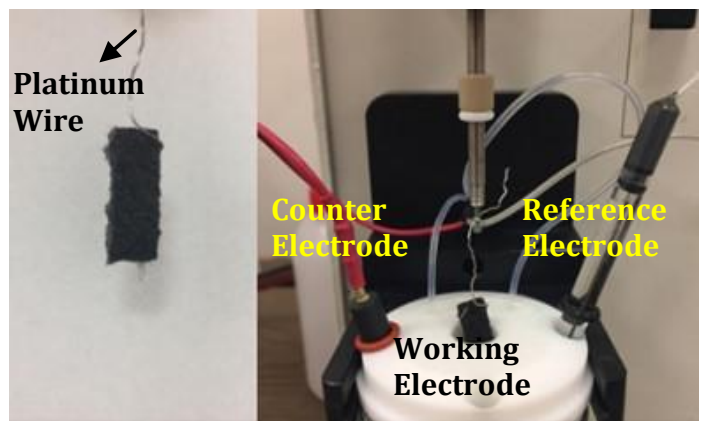

Figure1. Electrodes used for CV, LSV and installation of working electrode.

\section{Results and Discussion}

\subsection{Characterization of electrodes}

The surface morphology of the graphite felts was detected with scanning electron microscopy analysis. Graphite felt fiber diameter for the modified graphite felt decreases as a result of corrosion effect of the $\mathrm{HF}$ (Figure 2 (a) and Figure 2 (c)). After $\mathrm{HF}$ and $\mathrm{H}_{2} \mathrm{O}_{2}$ modification carbon nanoparticles which are broken off from felt occur as reported in a previous study [23](Figure 2 (d)). The formation of such carbon particles on the electrode surface is expected to increase the surface area and porosity by the formation of indentations on the surface as a result of acid and peroxide modification. In addition to increase in surface area and porosity of the electrode, bonding of the oxygen containing groups with $\mathrm{H}_{2} \mathrm{O}_{2}$ treatment is desirable since these groups provide advantages such as wettability and catalytic active sites for chromium redox reaction [29].

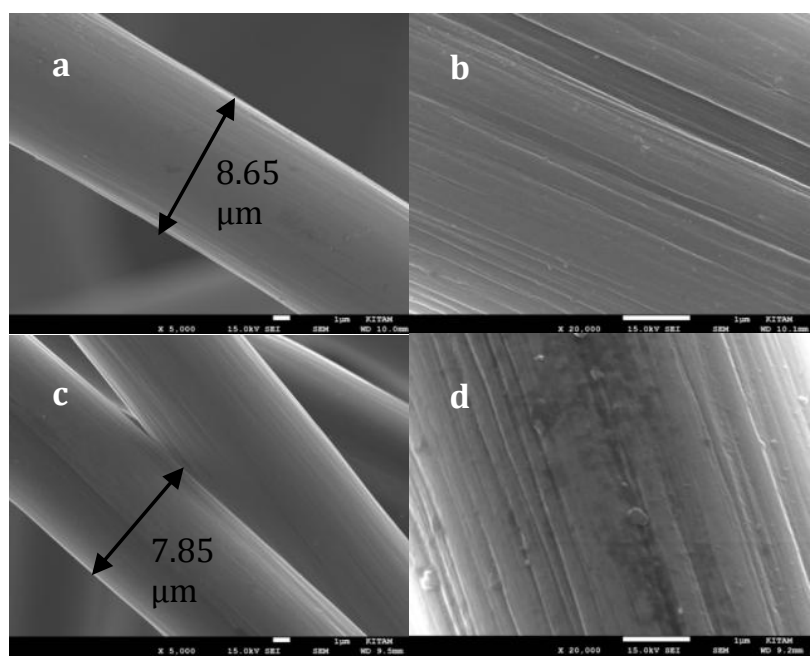

Figure 2. SEM micrographs of GF (a, b) and HF-GF (c, d) electrodes.

Bismuth is seen as attached to the electrode surface from electrochemically bismuth deposited electrode's SEM images (Figure 3). Bismuth surface density could be seen from mapping results and Bi particles loaded on the GF electrode are observed as agglomerated on the surface (Figure 3 (b) inset). On the other hand, bismuth particles are smaller and homogeneously dispersed on the Bi/HF-GF electrode compared to $\mathrm{Bi} / \mathrm{GF}$ electrode thanks to the hydrophilic structure of the HF-GF electrode (Figure 3 (d)). In addition to hydrophilic structure, carbon nanoparticles on the HF-GF electrode are thought to allow effective distribution of bismuth on the surface.

XPS spectrum was obtained for the determination of surface chemistry and functional groups. Wide scan XPS 
survey spectra between $0-1300 \mathrm{eV}$ was given in Figure 4. Peak position of the carbon $1 \mathrm{~s}$ is at $284.6 \mathrm{eV}$ binding energy and surface elemental composition is found as oxygen and carbon. 01s peak intensity increases for the $\mathrm{HF}-\mathrm{GF}$ electrode and oxygen percentage is 3.7\% higher than the pristine GF (Table 1).

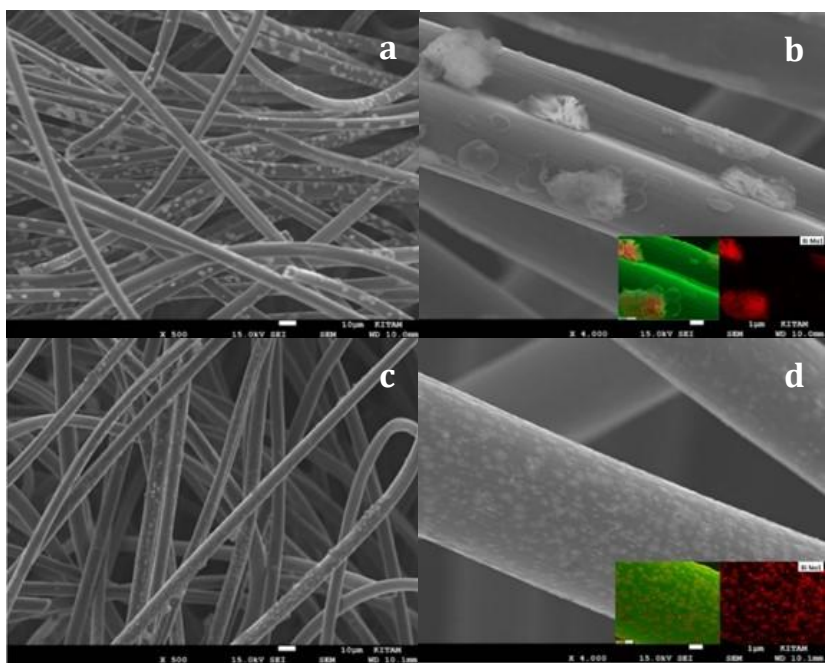

Figure 3. SEM micrographs and bismuth, oxygen mapping for $\mathrm{Bi} / \mathrm{GF}(\mathrm{a}, \mathrm{b})$ and $\mathrm{Bi} / \mathrm{HF}-\mathrm{GF}(\mathrm{c}, \mathrm{d})$ electrodes.

Curve fitted C1s and 01s spectrums were given in Figure 5 and carbon in C1s spectra and oxygen in 01s spectra has various electronic states. Functional groups on the surface and binding energies according to $\mathrm{C} 1 \mathrm{~s}$ spectra as follows: $\mathrm{C}=\mathrm{C}(284.0,283.75 \mathrm{eV})$ [30], C-C (284.7, $284.9 \mathrm{eV})$ [10], [13], [27], [31], C-OH (286.0, $285.75,285.9 \mathrm{eV})[10],[12],[13],[31], \mathrm{C}=0$ (287.0, 288.0, 529.9, 531.1, 531.3, 531.8 eV) [10], [31]-[34] (10,31-34), carboxyl group $(288.8,289.75,291.0 \mathrm{eV})$ [33], [35], -OH (532.8 eV) [35] and water (533.6, 534.2 eV) [31], [32].

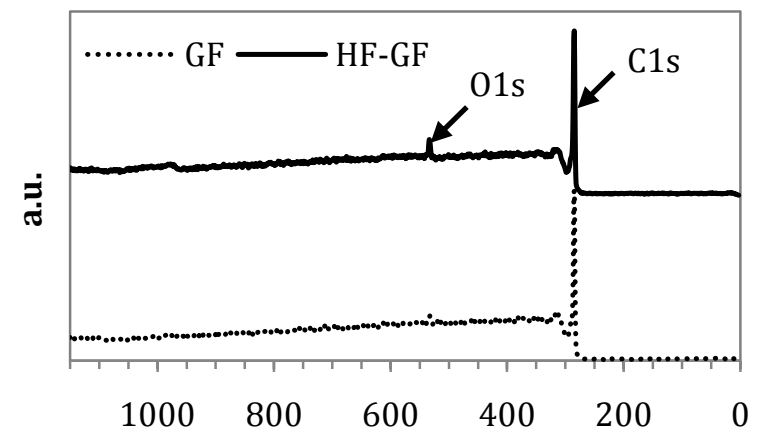

Binding Energy/eV

Figure 4. Wide scan XPS spectra for GF and HF-GF electrodes.

Percentage of functional groups obtained after deconvolution were given in Table 1. C-C group percentage increases after chemical modification. The carbon double bond structure reduces to a single bond and thus the percentage of $\mathrm{C}-\mathrm{C}$ may be higher as a result of the occurrence of oxygen containing groups. Unlike $\mathrm{C}$ $\mathrm{OH}$ percentage, the amount of carboxyl group increases. This suggests that $\mathrm{C}-\mathrm{OH}$ forms may be converted into carboxyl groups. $\mathrm{C}=\mathrm{O}$ and water percentages increase for HF-GF electrode according to 01s spectra. Adsorbed water increases on the surface a result of acquired hydrophilic property of HF-GF. The presence of acidic oxygen containing groups on the surface increases the hydrophilic character of the structure, thus these groups facilitate access to the active areas for the electrolyte [10], [14], [23]. Moreover, it is known that the presence of -OH groups in the structure facilitate electron transfer [7], [9].

Table 1 . The contents of carbon, oxygen and surface functional groups of GF and HF-GF electrodes obtained from XPS data

\begin{tabular}{|c|c|c|c|c|c|c|c|c|}
\hline & \multicolumn{4}{|c|}{ C1s (\%) } & \multicolumn{4}{|c|}{ 01s (\%) } \\
\hline GF & \multicolumn{4}{|c|}{97.4} & \multicolumn{4}{|c|}{2.6} \\
\hline HF-GF & \multicolumn{4}{|c|}{93.7} & \multicolumn{4}{|c|}{6.3} \\
\hline & \multicolumn{4}{|c|}{ C1s } & & \multicolumn{3}{|c|}{$01 \mathrm{~s}$} \\
\hline & $\mathrm{C}=\mathrm{C}$ & C-C & $\mathrm{C}-\mathrm{OH}$ & $\mathrm{C}=0$ & $\mathrm{O}=\mathrm{C}-\mathrm{OH}$ & $\mathrm{C}=\mathrm{O}$ & $\mathrm{OH}$ & $\mathrm{H}_{2} \mathrm{O}$ \\
\hline GF & 15.3 & 32.9 & 29.9 & 19.4 & 2.5 & 43.7 & 28.8 & 27.5 \\
\hline HF-GF & 16.3 & 43.1 & 26.2 & 8.3 & 6.2 & 50.6 & 18.5 & 30.9 \\
\hline
\end{tabular}

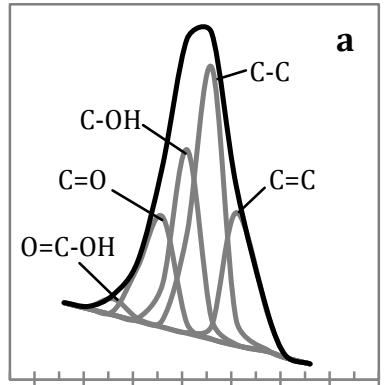

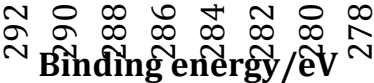

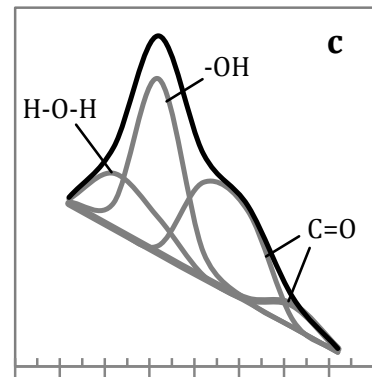

மำ

Bînding ènergy $/ \mathrm{eV}$

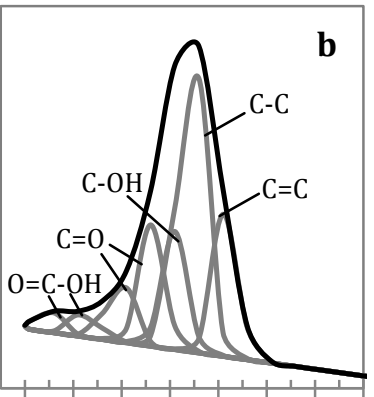

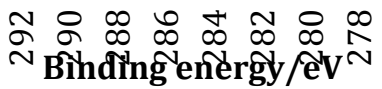

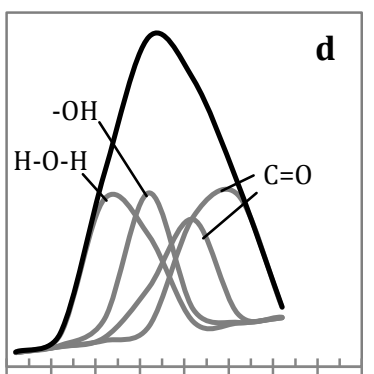

ஸి Binding energy/ể
Figure 5. Deconvoluted XPS C1s spectra for GF (a) and HF-GF (c) electrodes and 01s spectra for GF (b) and HF$\mathrm{GF}(\mathrm{d})$ electrodes 
Wettability tests were achieved by dynamic contact angle measurement and showed in Figure 6. Initial contact angle for pristine GF is $132.6^{\circ}$ and it decreased to $128.5 \square$ after modification. Absorption of water droplet for HF-GF electrode is faster than the pristine one with the help of oxygen containing groups on the HF-GF (Figure 6).

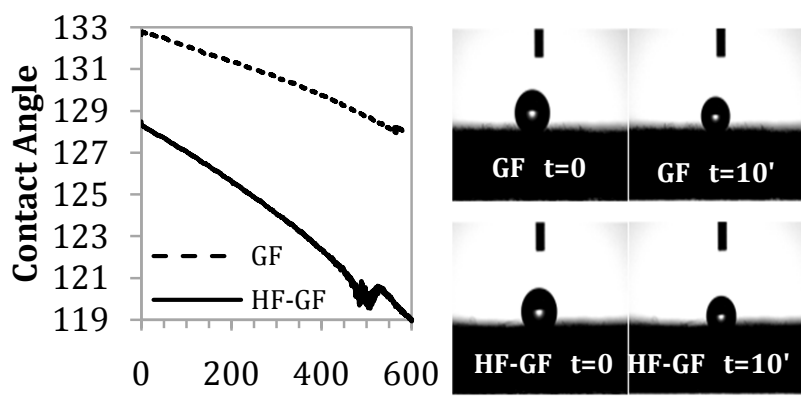

Time/s

Figure 6. Dynamic contact angle measurement graphs and water drop $(5 \mu \mathrm{l})$ images

\subsection{Application of electrodes for $\mathrm{Cr}$ side of $\mathrm{Fe} / \mathrm{Cr}$ flow battery}

Cyclic voltammetry was used to investigate the reduction and oxidation behavior of chromium ions and bismuth ions, proton adsorption and desorption on the electrode surface. Voltammograms obtained with the GF and HF-GF electrodes in $1 \mathrm{M} \mathrm{HCl}$ electrolyte were given in Figure 7. Potential sweeping was performed from the positive potential to the negative potential at the scanning rate of $100 \mathrm{mV} / \mathrm{s}$ between $1.0 \mathrm{~V}$ and $-0.2 \mathrm{~V}$ to observe proton adsorption and desorption on the surface. Peaks for the proton adsorption and desorption are seen at $0.075 \mathrm{~V}$ and $0.875 \mathrm{~V}$ for the GF electrode and $0.175 \mathrm{~V}$ and $0.825 \mathrm{~V}$ for the HF-GF electrode respectively [36]. It is seen that the peaks observed for HF-GF electrode approach each other and the potential difference between peaks $\left(\Delta \mathrm{E}_{\mathrm{p}}\right)$ decreases as $0.15 \mathrm{~V}$ compared to GF electrode. This shows that the proton adsorption desorption becomes more reversible on the HF-GF electrode. The increase in peak current density for the HF-GF electrode is related to the higher proton concentration on the surface of the HF-GF electrode, which has hydrophilic structure [10].

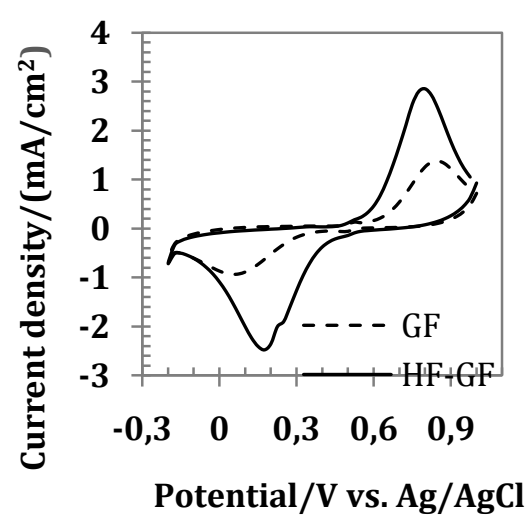

Figure 7. CV curves between $(+1.0)-(-0.2) \mathrm{V}$ for the GF and $\mathrm{HF}-\mathrm{GF}$ electrodes in $1 \mathrm{M} \mathrm{HCl}$ electrolyte, with the $100 \mathrm{mV} / \mathrm{s}$ scan rate

Cyclic voltammetry curves (CVs) for graphite felt (GF) working electrode in both bismuth containing and bismuth free chromium electrolyte and Bi/GF working electrode in bismuth free chromium electrolyte were given in Figure 8 (a). Peak positions were also summarized in table $2 . \mathrm{Cr}^{2+} / \mathrm{Cr}^{3+}$ anodic peak is seen around $0.5 \mathrm{~V}$ when $\mathrm{CV}$ curve obtained under bismuth catalyst free conditions (both in electrolyte and on the felt). The $\mathrm{Cr}^{2+} / \mathrm{Cr}^{3+}$ cathodic peak is not observed on the $\mathrm{CV}$ curve since the cathodic peak cannot be distinguished due to the formation of hydrogen gas. When bismuth is added to the solution, there is a small cathodic peak around $-0.2 \mathrm{~V}$ and anodic peak around $0.1 \mathrm{~V}$. In the study of Yang et al. [20], the saturated calomel electrode was used and $\mathrm{Bi}^{3+}$ reduction and $\mathrm{Bi}$ oxidation peaks were reported to be around -0.2 and $0 \mathrm{~V}$ respectively. (These values correspond to -0.12 and $+0.08 \mathrm{~V}$ respectively, according to the $\mathrm{Ag} / \mathrm{AgCl}$ reference electrode). When electrochemically bismuth deposited felt $(\mathrm{Bi} / \mathrm{GF})$ is used as working electrode, the bismuth anodic peak can be seen in a severe manner around 0.1 $\mathrm{V}$. The anodic peak is much higher than the cathodic peak for both cases which bismuth is present in the solution and on the graphite felt since $\mathrm{Bi}^{3+}$ ions are very dense on the surface. However, $\mathrm{Cr}$ anodic peak is not observed next to bismuth peak on CV curves. Bismuth anodic peak shifts to more positive potential for bismuth loaded electrode (Bi/GF) unlike the case which bismuth is in the electrolyte solution and this peak also involves the $\mathrm{Cr}$ anodic peak around $0.5 \mathrm{~V}$. 

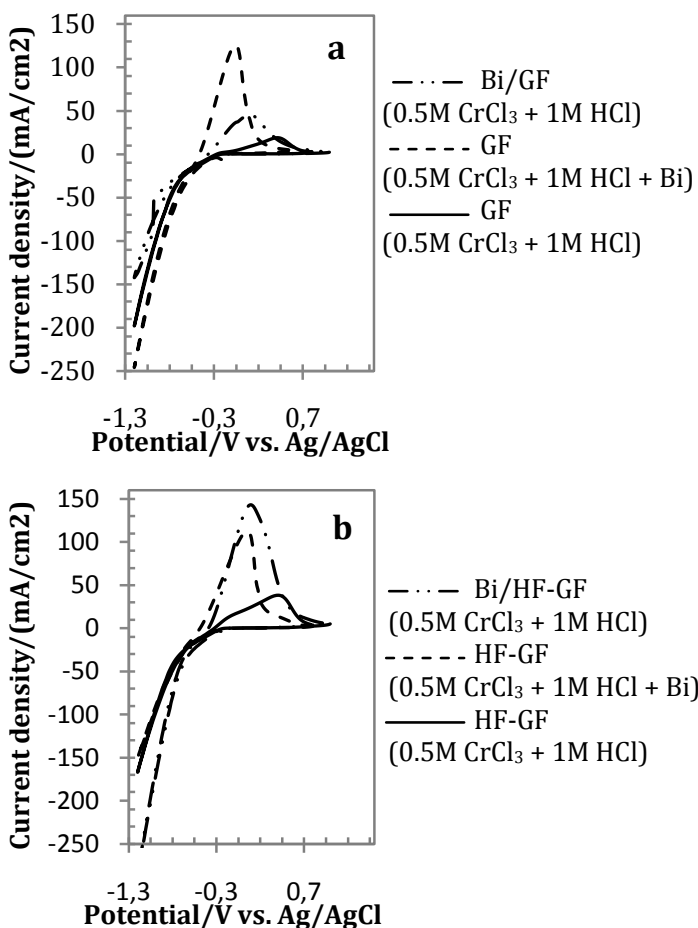

Figure 8. CV curves for GF and Bi/GF electrodes (a), HF$\mathrm{GF}$ and Bi/HF-GF electrodes (b) in different electrolyte solutions at $100 \mathrm{mV} / \mathrm{s}$ scan rate

Table 2 Peak positions and $\mathrm{H}_{2}$ evolution potentials for electrodes

\begin{tabular}{lcccc} 
& GF & HF-GF & Bi/GF & Bi/HF-GF \\
\hline Peak position $^{*}$ & $0.40 \mathrm{~V}$ & $0.40 \mathrm{~V}$ & $0.10 \mathrm{~V}$ & $0.40 \mathrm{~V}$ \\
$\begin{array}{l}\text { H2 evolution } \\
\text { potential }^{* *}\end{array}$ & $-0.20 \mathrm{~V}$ & $-0.20 \mathrm{~V}$ & $-0.10 \mathrm{~V}$ & $-0.18 \mathrm{~V}$
\end{tabular}

${ }^{*}$ In $0.5 \mathrm{M} \mathrm{CrCl}_{3}+1 \mathrm{M} \mathrm{HCl}$ electrolyte and at $100 \mathrm{mV} / \mathrm{s}$ scan rate

** In $1 \mathrm{M} \mathrm{HCl} \mathrm{electrolyte} \mathrm{and} \mathrm{at} 50 \mathrm{mV} / \mathrm{s}$ scan rate

Cyclic voltammetry curves (CVs) for HF-GF working electrode in both bismuth containing and bismuth free chromium electrolyte and Bi/HF-GF working electrode in bismuth free chromium electrolyte were given in Figure 8 (b). In the CV curve obtained in bismuth-free conditions, $\mathrm{Cr}^{2+} / \mathrm{Cr}^{3+}$ anodic peak is seen around $0.5 \mathrm{~V}$. The current density value of this peak increases by 20 $\mathrm{mA} / \mathrm{cm} 2$ compared to the untreated felt on the HF-GF electrode. In addition, there is a relatively small hysteresis opening around $-0.8 \mathrm{~V}$. The hysteresis in this region may be due to the interaction between hydrogen and acidic groups on the HF-GF electrode or may be due to the $\mathrm{Cr}^{3+}$ reduction reaction. In the case which bismuth catalyst is in solution, bismuth cathodic peak and anodic peak are seen around $-0.2 \mathrm{~V}$ and $0.05 \mathrm{~V}$ respectively and their positions shift to $0.1 \mathrm{~V}$ right compared to GF electrode as seen. The fact that the anodic peak shifts to the right side reduces the reversibility, this does not seem to be a problem since the oxidation of bismuth is not desirable.

When the Bi/HF-GF and Bi/GF electrodes compared, the intensity of the bismuth anodic peak is much higher on the HF-GF electrode and the peak position is seen at more negative value. It is thought that, bismuth peak is more severe hence surface of the fibers is covered with bismuth for $\mathrm{Bi} / \mathrm{HF}-\mathrm{GF}$ electrode. In addition, this peak covers the potential value of $\mathrm{Cr}^{2+}$ anodic peak. Although the $\mathrm{Cr}$ anodic peak cannot be distinguished on Bi/GF and Bi/HFGF electrodes clearly, the current density value around $0.5 \mathrm{~V}$ is higher on the $\mathrm{Bi} / \mathrm{HF}-\mathrm{GF}$ electrode. According to the Randles-Sevcik equation (Equation 1), the diffusion coefficient can be obtained from the slope of the line when scan rate is plotted against the current [11], [37]. In this equation $\mathrm{A}$ is electrode area, D is diffusion coefficient, $\mathrm{n}$ is number of transferred electrons, $\vartheta$ is scan rate, $\mathrm{C} 0$ is concentration, $\alpha$ is charge transfer coefficient ( 0.5$)$ and Ip is peak current.

$$
I_{p}=2,69 \times 10^{5} A D^{1 / 2} n^{3 / 2} \vartheta^{1 / 2} C
$$

The CV curves for GF and HF-GF electrodes at different scan rates in $0.5 \mathrm{M} \mathrm{CrCl}_{3}+1 \mathrm{M} \mathrm{HCl}$ solution were given in Figure 9. The high intensity of the $\mathrm{Cr}^{2+}$ anodic peak on the HF-GF electrode at different scan rates indicates that the polarization is lower on HF-GF electrode. The linearity of the lines shows that the reaction is controlled by charge transfer for both GF and HF-GF electrodes [31]. In the peak current against the square root of scan rate graphs, the slope of the line is higher in the HF-GF electrode and diffusion coefficient on the HFGF electrode is twice that of the GF electrode. Diffusion coefficients of $\mathrm{Cr}^{2+}$ on $\mathrm{GF}$ and $\mathrm{HF}-\mathrm{GF}$ electrodes are $2.3 \times 10^{-6} \mathrm{~cm}^{2} / \mathrm{s}, 4.7 \times 10^{-6} \mathrm{~cm}^{2} / \mathrm{s}$ respectively. $\mathrm{Cr}$ peak on the GF electrode could not be distinguished in CV curves taken at different scan rates in the bismuth containing $0.5 \mathrm{M} \mathrm{CrCl}_{3}+1 \mathrm{M} \mathrm{HCl}$ solution, so the graph could not be plotted. $\mathrm{Cr}$ peak could not be seen due to ineffectiveness of $\mathrm{Cr}^{2+}$ ions diffusion on GF electrode. On the HF-GF electrode, the graph is plotted because the current density value for $\mathrm{Cr}^{2+}$ is higher and it can be seen that the slope of the line in this graph is decreased compared to the bismuth free condition. The diffusion constant for $\mathrm{Cr}^{2+}$ ions is approximately four times lower $\left(0.8 \times 10^{-6}\right.$ $\mathrm{cm}^{2} / \mathrm{s}$ ) than the bismuth free condition when bismuth ions are present in solution. On the other hand, charge transfer becomes easier in the bismuth containing electrolyte solution [31]. Although the peak separation could not be made for $\mathrm{Cr}$ when the bismuth catalyst is in solution, the current density value decreases linearly with the decrease in the voltage scan rate. On the contrary, when the bismuth catalyst is loaded to electrode, the decrease in peak current does not show a linearity. This showed that reaction becomes diffusion controlled when the bismuth catalyst is loaded on the felt.

Linear sweeping voltammetry graphs for monitoring hydrogen evolution on GF, HF-GF, Bi/GF and Bi/HF-GF electrodes show that hydrogen evolution is suppressed better on HF-GF electrode (Figure 10). This is directly related to the oxygen containing groups formed on the 
HF-GF electrode. Formation of hydrogen is inhibited by bonding protons with oxygen groups located on the electrode surface. The proton concentration on the surface of the HF-GF electrode is higher as previously mentioned (Figure 7). Metallic bismuth and protons form $\mathrm{BiH}_{3}$ solid as given below. As a result, bismuth inhibits evolution of hydrogen gas by forming $\mathrm{BiH}_{3}$ solids [19], [20], [32].

$$
\begin{array}{ll}
\mathrm{Bi}^{3+}+3 \mathrm{e}^{-} \rightarrow \mathrm{Bi} & 0.308 \mathrm{~V} \text { vs SHE } \\
& 0.109 \mathrm{~V} \text { vs. Ag/AgCl (3M NaCl) } \\
\mathrm{Bi}+3 \mathrm{H}^{+}+3 \mathrm{e}^{-} \rightarrow \mathrm{BiH}_{3} & -0.8 \mathrm{~V} \text { vs SHE } \\
& -1.0 \mathrm{~V} \text { vs. Ag/AgCl (3M NaCl) }
\end{array}
$$

$\mathrm{Bi} / \mathrm{HF}-\mathrm{GF}$ electrode is better than $\mathrm{Bi} / \mathrm{GF}$ electrode to suppress hydrogen evolution. The change in current density around $-1.0 \mathrm{~V}$ is considered to be caused by formation of $\mathrm{BiH}_{3}$ solid on the Bi/HF-GF and $\mathrm{Bi} / \mathrm{GF}$ electrodes. Although the formation of hydrogen gas on the bismuth free electrodes appear to be less in the LSV curves, it is thought that, bismuth loaded electrodes may be more effective to suppress hydrogen evolution for long term operations. 

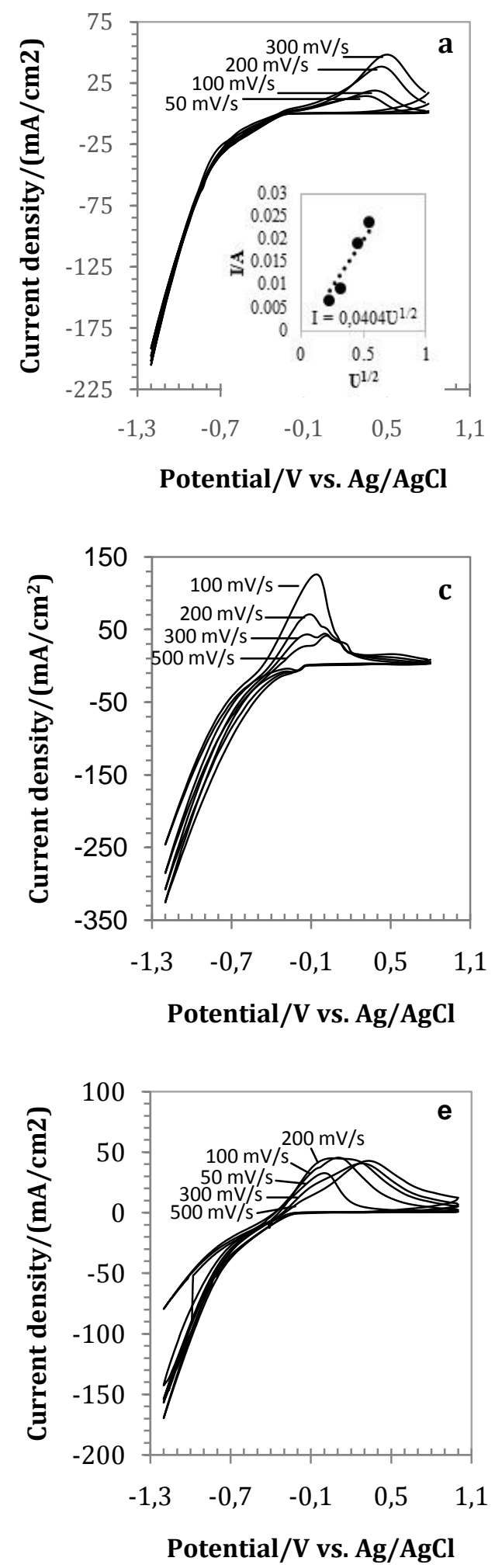

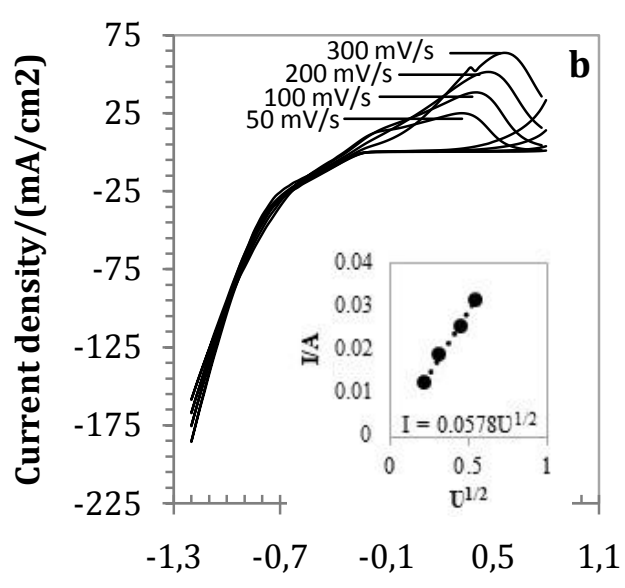

Potential/V vs. Ag/AgCl
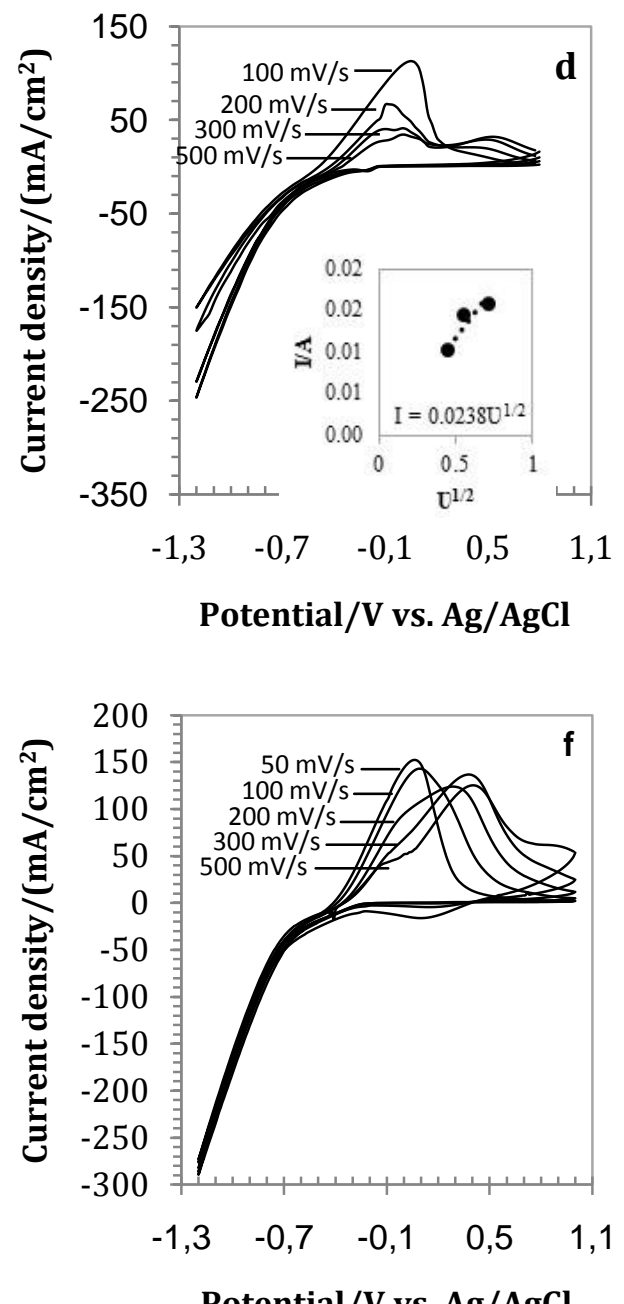

Potential/V vs. Ag/AgCl

Figure 9. $\mathrm{CV}$ curves of $\mathrm{GF}(\mathrm{a}), \mathrm{HF}-\mathrm{GF}(\mathrm{b})$ in $1 \mathrm{M} \mathrm{HCl}+0.5 \mathrm{M} \mathrm{CrCl}_{3}$ electrolyte, $\mathrm{GF}$ (c), $\mathrm{HF}-\mathrm{GF}$ (d) in $1 \mathrm{M} \mathrm{HCl}+0.5 \mathrm{M} \mathrm{CrCl}{ }_{3}+$ $0.005 \mathrm{~g} \mathrm{Bi} / \mathrm{cm}^{2}$ electrolyte, $\mathrm{Bi} / \mathrm{GF}(\mathrm{e}), \mathrm{Bi} / \mathrm{HF}-\mathrm{GF}$ (f) in $1 \mathrm{M} \mathrm{HCl}+0.5 \mathrm{M} \mathrm{CrCl}_{3}$ electrolyte at different scan rates. 


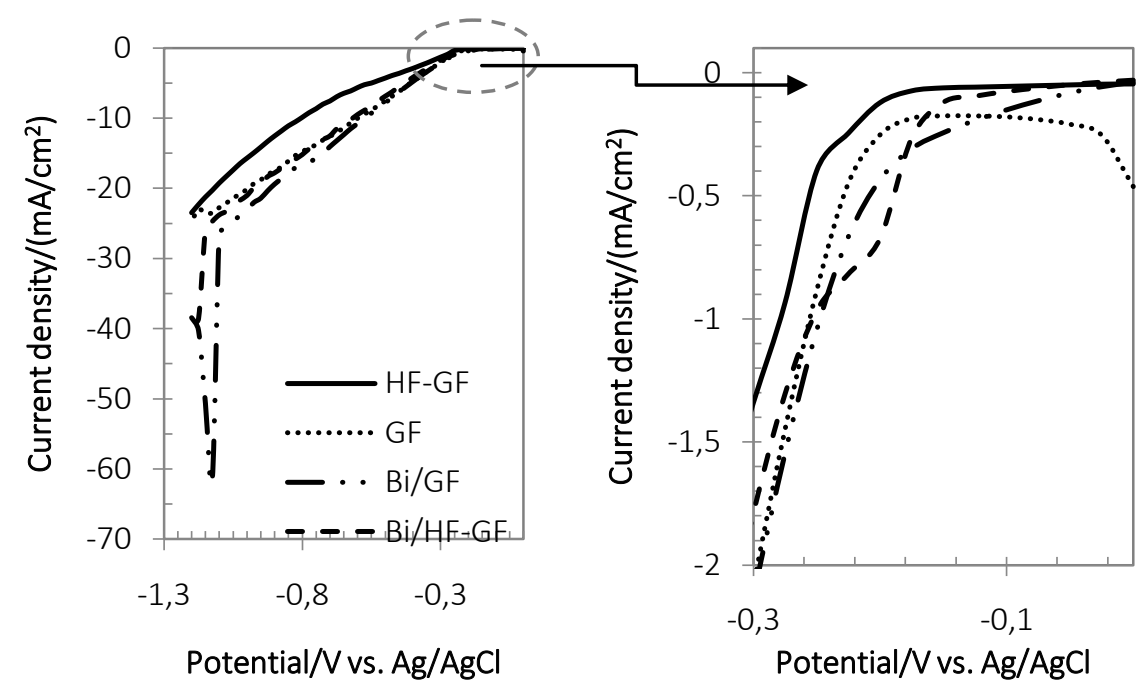

Figure 10. LSV curves of GF, HF-GF, Bi/GF and Bi/HF-GF electrodes in $1 \mathrm{M} \mathrm{HCl}$ and $50 \mathrm{mV} / \mathrm{s}$ scan rate

\section{Conclusion}

In summary, corrosive $\mathrm{HF}$ and oxidizing $\mathrm{H}_{2} \mathrm{O}_{2}$ were used to obtain a porous and hydrophilic electrode structure. The effect of electrode structure and double acting bismuth material which shows feature as catalyst and hydrogen evolution suppressor agent on the $\mathrm{Cr}^{2+} / \mathrm{Cr}^{3+}$ redox pair were investigated. Contact angle for graphite felt decreased to $128.5^{\circ}$ after modification. The wettability of the felt treated with $\mathrm{HF}$ and $\mathrm{H}_{2} \mathrm{O}_{2}$ increased and as a result, reactant concentration on the surface increased. Hydrogen evolution decreased compared to other electrodes with the oxygen containing groups formed on the surface of the HF-GF electrode. However, bismuth loaded HF/GF is going to be better to prevent hydrogen formation since $\mathrm{BiH}_{3}$ solid consists on the electrode. GF and HFGF electrodes are charge transfer controlled but the diffusion coefficient for the HF-GF electrode is twice compared to GF electrode. Although the peak separation for $\mathrm{Cr}$ could not be seen clearly when the bismuth catalyst was in electrolyte, the current density value decreased linearly with the decrease in the voltage scan rate. This indicates that the reaction is still under charge transfer control. On the contrary, when the bismuth catalyst is loaded onto the felt, the reaction is controlled by diffusion.

\section{Acknowledgment}

Authors gratefully acknowledge the financial support by Ondokuz Mayıs University scientific research project through grant number PYO.MUH.1904.16.013.

\section{References}

[1] J. Baker, "New technology and possible advances in energy storage," Energy Policy, vol. 36, pp. 4368-
4373, 2008.

[2] C. R. Dennison, E. Agar, B. Akuzum, and E. C. Kumbur, "Enhancing Mass Transport in Redox Flow Batteries by Tailoring Flow Field and Electrode Design," J. Electrochem. Soc., vol. 163, no. 1, pp. A5163-A5169, 2016.

[3] Y. K. Zeng, T. S. Zhao, L. An, X. L. Zhou, and L. Wei, “A comparative study of all-vanadium and ironchromium redox $\mathrm{fl}$ ow batteries for large-scale energy storage," J. Power Sources, vol. 300, pp. 438443, 2015.

[4] D. A. Johnson and M. A. Reid, "Chemical and Electrochemical Behavior of the $\mathrm{Cr}(\mathrm{lll}) / \mathrm{Cr}(\mathrm{ll})$ HalfCell in the Iron-Chromium Redox Energy Storage System," J. Electrochem. Soc., vol. 132, no. 5, pp. 1058-1062, 1985.

[5] T. X. H. Le, M. Bechelany, and M. Cretin, "Carbon felt based-electrodes for energy and environmental applications: A review," Carbon N. Y., vol. 122, pp. 564-591, 2017.

[6] P. Leung, X. Li, C. P. De Leon, L. Berlouis, C. T. John Low, and F. C. Walsh, "Progress in redox flow batteries, remaining challenges and their applications in energy storage," RSC Adv., vol. 2, no. 27, pp. 10125-10156, 2012.

[7] M. Sun, B., Skyllas Kazacos, "Modification of Graphite Electrode Materials for Vanadium Redox Flow Battery Application-I. Thermal Treatment," Electrochim. Acta, vol. 37, no. 1, pp. 1253-1260, 1992.

[8] P. Mazúr et al., "Performance evaluation of thermally treated graphite felt electrodes for vanadium redox fl ow battery and their four-point single cell characterization," J. Power Sources, vol. 380, pp. 105114, 2018.

[9] B. Sun and M. Skyllas Kazacos, "Chemical Modification of Graphite Electrode Materials for Vanadium Redox Flow Battery Application-Part II. Acid Treatments," Electrochim. Acta, vol. 37, no. 13, pp. 2459-2465, 1992. 
[10] L. Yue, W. Li, F. Sun, L. Zhao, and L. Xing, "Highly hydroxylated carbon fibres as electrode materials of all-vanadium redox flow battery," Carbon N. Y., vol. 48, pp. 3079-3090, 2010.

[11] X. Li, K. Huang, S. Liu, and L. Chen, "Electrochemical behavior of diverse vanadium ions at modified graphite felt electrode in sulphuric solution," J. Cent. South Univ. Technol., vol. 14, no. 1, pp. 51-56, 2007.

[12] X. Li, K. Huang, S. Liu, N. Tan, and L. Chen, "Characteristics of graphite felt electrode electrochemically oxidized for vanadium redox battery application," Trans. Nonferrous Met. Soc. China, vol. 17, no. 1, pp. 195-199, 2007.

[13] L. Estevez et al., "Tunable Oxygen Functional Groups as Electrocatalysts on Graphite Felt Surfaces for AllVanadium Flow Batteries," ChemSusChem, vol. 9, no. 12, pp. 1455-1461, 2016.

[14] E. Hollax and D. S. Cheng, "The Influence of Oxidative Pretreatment of Graphite Electrodes on The Catalysis of The $\mathrm{Cr} 3+$ / $\mathrm{Cr} 2+$ and $\mathrm{Fe} 3+$ / $\mathrm{Fe} 2+$ Redox Reactions," Carbon N. Y., vol. 23, no. 6, pp. 655-664, 1985.

[15] Y. K. Zeng, T. S. Zhao, X. L. Zhou, L. Zeng, and L. Wei, "The effects of design parameters on the chargedischarge performance of iron-chromium redox flow batteries," Appl. Energy, vol. 182, pp. 204-209, 2016.

[16] Y. K. Zeng, X. L. Zhou, L. Zeng, X. H. Yan, and T. S. Zhao, "Performance enhancement of iron-chromium redox flow batteries by employing interdigitated flow fields," J. Power Sources, vol. 327, pp. 258-264, 2016.

[17] B. Li et al., "Bismuth Nanoparticle Decorating Graphite Felt as a High- Performance Electrode for an All-Vanadium Redox Flow Battery," Nanoletters, vol. 13, no. 3, pp. 1330-1335, 2013.

[18] Z. González, A. Sánchez, C. Blanco, M. Granda, R. Menéndez, and R. Santamaría, "Enhanced performance of a Bi-modified graphite felt as the positive electrode of a vanadium redox fl ow battery," Electrochem. commun., vol. 13, pp. 1379-1382, 2011.

[19] D. J. Suárez, Z. González, C. Blanco, M. Granda, R. Menéndez, and R. Santamaría, “Graphite felt modified with bismuth nanoparticles as negative electrode in a vanadium redox flow battery," ChemSusChem, vol. 7, pp. 914-918, 2014.

[20] X. Yang, T. Liu, C. Xu, H. Zhang, X. Li, and H. Zhang, "The catalytic effect of bismuth for $\mathrm{VO} 2+/ \mathrm{VO} 2+$ and $\mathrm{V} 3+/ \mathrm{V} 2+$ redox couples in vanadium flow batteries," J. Energy Chem., vol. 26, no. 1, pp. 1-7, 2017.

[21] C. D. Wu, D. A. Scherson, E. J. Calvo, and E. B. Yeager, "A Bismuth-Based Electrocatalyst for the ChromousChromic Couple in Acid Electrolytes," J. Electrochem. Soc., vol. 133, no. 10, pp. 2109-2112, 1986.

[22] A. Z. Weber, M. M. Mench, J. P. Meyers, P. N. Ross, J. T. Gostick, and Q. Liu, "Redox flow batteries : a review," J. Appl. Electrochem., vol. 41, pp. 1137-1164, 2011.

[23] Z. He et al., "HF / H2O2 treated graphite felt as the positive electrode for vanadium redox flow battery," Appl. Surf. Sci., vol. 423, pp. 111-118, 2017.

[24] X. L. Zhou, Y. K. Zeng, X. B. Zhu, L. Wei, and T. S. Zhao, "A high-performance dual-scale porous electrode for vanadium redox fl ow batteries," J. Power Sources, vol. 325, pp. 329-336, 2016.

[25] Z. Zhang, J. Xi, H. Zhou, and X. Qiu, "KOH etched graphite felt with improved wettability and activity for vanadium flow batteries," Electrochim. Acta, vol. 218, pp. 15-23, 2016.

[26] L. Zhou, Z. Hu, C. Zhang, Z. Bi, T. Jin, and M. Zhou, "Electrogeneration of hydrogen peroxide for electroFenton system by oxygen reduction using chemically modified graphite felt cathode," Sep. Purif. Technol., vol. 111, pp. 131-136, 2013.

[27] L. Zhou, M. Zhou, Z. Hu, Z. Bi, and K. G. Serrano, "Chemically modified graphite felt as an efficient cathode in electro-Fenton for $\mathrm{p}$-nitrophenol degradation," Electrochim. Acta, vol. 140, pp. 376383, 2014.

[28] R. E. G. Smith, T. J. Davies, N. D. B. Baynes, and R. J. Nichols, "The electrochemical characterisation of graphite felts," J. Electroanal. Chem., vol. 747, pp. 2938,2015 .

[29] K. J. Kim, M.-S. Park, Y.-J. Kim, S. X. Dou, and M. Skyllas-Kazacos, "A technology review of electrodes and reaction mechanisms in vanadium redox flow batteries," J. Mater. Chem. A, vol. 3, no. 33, pp. 1691316933, 2015.

[30] G. Wei, C. Jia, J. Liu, and C. Yan, “Carbon felt supported carbon nanotubes catalysts composite electrode for vanadium redox flow battery application," J. Power Sources, vol. 220, pp. 185-192, 2012.

[31] C. Gao et al., "Influence of Fenton's reagent treatment on electrochemical properties of graphite felt for all vanadium redox flow battery," Electrochim. Acta, vol. 88, pp. 193-202, 2013.

[32] H. Zhang, Y. Tan, J. Li, and B. Xue, "Studies on properties of rayon- and polyacrylonitrile-based graphite felt electrodes affecting $\mathrm{Fe} / \mathrm{Cr}$ redox flow battery performance," Electrochim. Acta, vol. 248, pp. 603-613, 2017.

[33] Z. Gonzalez et al., "Outstanding electrochemical performance of a graphene-modified graphite felt for vanadium redox flow battery application," J. Power Sources, vol. 338, pp. 155-162, 2017.

[34] D. M. Kabtamu, J. Chen, Y. Chang, and C. Wang, "Water-activated graphite felt as a high-performance electrode for vanadium redox fl ow batteries," J. Power Sources, vol. 341, pp. 270-279, 2017.

[35] J. Zhou et al., "Characterization of surface oxygen complexes on carbon nanofibers by TPD , XPS and FT-IR," Carbon N. Y., vol. 45, pp. 785-796, 2007.

[36] Q. Yin, N. P. Brandon, and G. H. Kelsall, "Electrochemical synthesis of $\mathrm{Cr}$ (II) at carbon electrodes in acidic aqueous solutions," J. Appl. Electrochem., vol. 30, pp. 1109-1117, 2000.

[37] C. Y. Yang, "Catalytic electrodes for the Redox Flow Cell energy storage device*," J. Appl. Electrochem., vol. 12, pp. 425-434, 1982. 